\title{
The Problem of International Understanding
}

\author{
By Gottfried Salomon Delatour
}

$I^{\mathrm{N}}$ THE United States of America there are dreamers of a United States of Europe. Those who believe in a future world government consider the unity or federation of Europe the most important step toward a world community. However, politically and culturally we are faced with two or many Europes. From the Elbe to Venezia Giulia runs a dividing line between west and east. This line goes through Germany. What we call Europe or the Occident, Western civilization or Pan-Europe, does not extend very far east from the frontiers of the old Roman Empire.

The German Reich of Bismarck tried to overcome the fundamental differences between the Germans west and east of the Elbe. There is a Germany of the west and south up to the Roman wall, the Limes Germanicus, which belonged to and was civilized by the Roman Empire, the Roman Catholic Church, the Renaissance, and Classicism; and there is a colonial GermanyPrussia, a feudal-military layer over a Slavic population. The old distinction of German liberals between political and cultural unity, between might and mind, is influenced by the heterogeneity of Germany.

It is evident that the actual border line of the present occupation does not correspond exactly to this boundary between the two Germanies, and that we have unnecessarily abandoned the land of the old Saxons, Middle Germany, to a new Slavic infiltration. A thousand years of Germanization will be liquidated now, and, in the reversal of the tide, the frontier at the Elbe or perhaps at the Oder will be the dividing line between two Europes.

However, the political struggle be- tween the Germanic and Slavic peoples is not the only division. Romanic Europe, the Western civilization centered in France, is entirely different from central European development. The Slavic, Germanic, and Romanic Europes have not only different languages, but different sets of traditions, customs, and values, and different styles of literature, art, morals, and religion. However, Protestantism and Catholicism are united in a common opposition against eastern Christendom. Only in the border regions from the Baltic Sea and Poland to Czechoslovakia and Croatia has the influence of Western Christendom been extended across the frontier. Eastern Christendom, since the fall of Constantinople, is the successor and heir to Byzantium. The idea of Moscow as the Third Rome following the Rome of antiquity and the Middle Ages was prevalent in all conceptions of Russia's mission. In the nineteenth century the Slavophiles developed this idea in a messianic view of the regeneration and reform of a decadent Europe by the native and original tradition of caesaropapism, the unity of spiritual and temporal power. The idea of Russia as the savior and the Orthodox Church as the model of community has influenced the policy of PanSlavism for a century.

\section{SOVIET EXPANSION}

Nevertheless, there has been an ambivalent Russian mind since Peter the Great. The long controversy between the Westerners who recognize the success of Western science and technology and the Slavophiles who desire the Russification of the Balts, the Poles, the Slovaks, and the southern Slavs con- 
tinues in actual Russian history. The Bolshevik Revolution tried by industrialization to catch up with western progress, but at the same time regarded Russia as in revolt against Europe, destined to lead the world along the path of regeneration. The occupation of strategic outposts as bulwarks of security and the temporary retreat into "socialism in one country" were different methods of making up the time lag between the developments in East and West. The new expansion is without limits. Union of Soviet Socialist Republics is the new title of a Russian empire-which title significantly does not mention Russia. It heralds a world empire through world revolution.

We have witnessed the defeat and retreat of Pan-Germanism and of the German assault on Europe. The Germans were not thinking of a state, but of a Reich similar to the Roman Empire of the German nation. Bismarck's Reich was only Little Germany, without Austria and all the minorities in central and southern Europe of German extraction and culture. Together with the Germons abroad, Hitler's propagandists counted 100 million Germans. German colonization and acculturation in the east is now terminated by the new minority policy expelling whole populations and shifting them to the "homeland."

The result of National Socialism is not only the extinction of the German cultural element in Slavic countries, but also the disintegration of the social structure of central Europe. We must not forget that Germans never passed through a revolution, like the English and the French. The middle class never came to power. They were a mass fluctuating between feudalism and proletarianism. Therefore, liberty and the democratization of liberties were always overshadowed by the need for protection against the rising proletarian movement. The proletarization of the whole nation is now a fact and a temptation to the Soviets to expand their power with a promise of alliance.

\section{SEPARATISM}

Europeans scarcely realized how much of the variety and richness of their civilization they owed to their common Christian tradition. For a thousand years they received a spiritual and ethical education. With the secularization of culture, separatism was encouraged and the nation-state of the French Revolution became a model. Nationalism brought together the fragmented Italian and German rules in centralized states. Freedom of the state was more important than freedom of men; liberties had to be sacrificed for national unity and security.

With industrialization, a policy of self-protection and progressive autarky set in. Customs unions and free trade areas were àlways limited. Economy (which is always political economy) gave no impetus to a larger unity. Economic nationalism brought new divisions. In the west, the whole of industrial Europe could never have supported its dense population without protectionism, and the richest countries were not those that traded with each other, but those that traded with the world. The east remained backward and dependent. There is thus a division of Europe into an industrial west and an agricultural east. In the separated parts of the old Austro-Hungarian Empire and the Balkans the peasants needed land and land reform more than industrial products. Economic exchange between these two Europes was always difficult, and lately possible only on a barter basis.

Hitler's solution, in his attempt to exploit all of Europe for German benefit, was the centralization of technological power in one country, depriving all other countries of industrial capacity, 
machinery, and manpower. The requisite of such a system was a strong German middle class, and the counterrevolution of National Socialism appeared at first to be a defense of and for the middle classes against a proletarian revolution. But for the sake of industrial rationalization in a war economy, all the small enterprises were liquidated, and the new masses, powerless and disorganized, were reduced to a proletarian status. The mass leaders proclaimed a mythological neo-barbarism of self-sacrifice for the sake of a collectivity of a superior race. All the resistance movements in occupied countries incorporated in Hitler's unity of Europe had to stress the idea of independence for all nations, small or large.

\section{European Federation and INTERNATIONALISM}

The polemical literature of the underground emphasized the defense of the Occident, first conceived by the Prime Minister of Henry IV of France, Sully. The modern political and cultural idea of a united Europe was a result of the French Revolution. Napoleon I presented himself as the executor of a European mission; he confessed to Las Cases that he dreamed of a victory of liberty and equality and one constitution for all countries of Europe. "The Russian war ought to have been the most popular of modern times. . . . Europe would soon in that way have made in fact but one people, and everyone, traveling all over it, would always have found himself in the common fatherland." 1 The ideal of enlightenment to unite interests and opinions, sentiments and principles, codes and customs, was a part of his legend.

The United States Constitution appeared to the French revolutionists as

1 Emmanuel de Las Cases, Mémorial de Sainte-Hélène, Nov. 11, 1816. the realization of their dreams, and our Ambassador Benjamin Franklin suggested an imitation of the American federation: "I do not see why you might not in Europe carry the Project of good Henry IV into Execution by forming a Federal Union and One Grand Republic of all its different States and Kingdoms."

Before the Congress of Vienna and Metternich's idea of a "Concert of Europe" of sovereign states, Conte de Saint-Simon, the founder of French socialism, wrote on the reorganization of European society (1814)..$^{2}$ His grand idea was based on the new industrialism and the development of public education. However, the industrial revolution, really unique in the history of civilization, did not change the political and social notions inherited from the preindustrialized world; liberalism and nationalism developed a kind of state which monopolized not only arms and taxes, but also education and history.

In the crisis of 1848 and at a Congress of Peace, Victor Hugo again evoked the ideal of European fraternity in the United States of Europe. It was more a republican policy against the dynasties than an antinationalist manifestation, like the pacifist and socialist movements after 1870 appealing to part of the people to unite against the military or capitalist ruling classes.

The "First Socialist International" developed a new idea of internationalism, based on the industrial development; the dictatorship of the proletariat should hasten the "withering away" of the nation-state, in spite of the admiration of the Marxists for the Jacobins of the French Revolution. Proudhon alone opposed the Marxist idea of a great centralized society relying upon the cultural principle which is traditionally

2 Pierre Renouvin, Les idées et les projets d'union européene au XIXe siècle, Dotation Carnegie, Bulletin 6, 1931. 
connected with community, region, or the small nation. ${ }^{3}$

In a secular age a pseudo religionthe nation-is today the object of worship to millions for whom church services are meaningless. All the prophets of a supranational community hoped that this national religion, with its symbols, rites, legends, and heroes, would become a matter of private concern like the confessions of Christian religion after the Thirty Years' War. They maintained the principle of cultural autonomy and international tolerance. The argument that a federation of $\mathbf{E u}-$ rope would destroy culture, folklore, and arts and crafts was met by Édouard Herriot in his book Europe, in which he cited the great enrichment that has always come to a country through contact with other cultures, particularly since the Renaissance. However, every national state has tried to use general education to safeguard its power and add to its own prestige. An explanation of the failure of the League of Nations and of the principle of self-determination of the national state was sought in the premature universalism-the attempt to include the whole world at once.

The idea of regional and federal unity cropped up again during the critical interval between the two world wars. Clement Attlee, parliamentary spokesman of the British Labor Party, declared officially in 1939:

There must be acceptance of the principle that international anarchy is incompatible with peace, and that in the common interest there must be recognition of an international authority superior to the individual States. . . Europe must federate or perish.

Between the two wars Great Britain, which is now calling for European federation, was moving toward a closer

${ }^{3}$ P. J. Proudhon, Du principe fédératif, 1863. and more exclusive Commonwealth and did not like to consider herself primarily part of Europe. Liberals like Sir Arthur Salter felt that any European economic union was impossible without the surrender of political sovereignty, for which England was quite unprepared. There was no hope from the socialist side, because the Social Democrats found themselves more nationalist than socialist in war and postwar times. The only step in the direction of Pan-Europe was Aristide Briand's declaration of a new policy of collective security. ${ }^{4}$

\section{Pan-Europe}

On September 5, 1929, Briand asked the Assembly of the League of Nations whether a "regional understanding," such as the League Covenant itself recommended, might not be attempted in Europe through "a political and social link which of course would in no way affect the sovereignty of the parties involved." In the spring of the following year, at the Assembly's suggestion, he adressed his famous "Memorandum on the Organization of a Regime of European Federal Union" to twenty-six European governments, outlining his proposal and asking for their comments.

Briand insisted that there could be no solution of the problems growing out of economic nationalism without political security, but for that he proposed little more than a new version of France's old demand for binding pledges of mutual assistance against aggression. He would set up a kind of European legislature on the model of the League's Assembly and Council, which would tackle the problems of the elimination of barriers to the free "circulation of goods, capital and individuals," the "establishment of a common market," and the "rational organization of production and of European exchanges."

4 Arthur Bingham, The United States of Europe, 1940, pp. $55 \mathrm{ff}$. 
European economic thought at that time was still dominated by the myth of American prosperity, which was believed to be due to the great "common market" of a continental area. By the time the twenty-six governments replied, the Great Depression was well under way. Even Britain was soon to abandon free trade, and every country was desperately trying to save its own economy at the expense of those of its neighbors.

Between the two world wars Count Richard Coudenhove-Kalergi outlined a working program of the Pan-European movement. He was fully aware that Europe was not a geographical concept and did not include England or Russia, explaining that the Pan American Union, as a model, does not include either Canada or the European colonies in America. Pan-Europe was to comprise twenty-seven states and four small territories with a population of about 300 million people in Europe proper, and with colonies in northern Africa adding another hundred million people to the European league.

The opposition to this movement was to be found in nationalist and communist circles. However, Russia, carrying out the first Five-Year Plan, was in no position to block a consolidation of Europe, and it was obvious that no single European nation could be a match for an industrialized Russia. As early as 1923 Coudenhove-Kalergi predicted that "the moment Russia recovers from her internal disruption, not Poland nor Rumania nor Czechoslovakia will be able to stem her onrush toward the West, and still less will the disarmed states of Hungary, Austria and Germany be able to do so." The logical conclusion was that Europe had but two courses of action: to consolidate in a federal union or to succumb to a Russian conquest.

The main reason for the failure of Coudenhove-Kalergi's plan was its lack of appeal to the masses. The PanEuropean plan was submitted to and applauded only by the representatives of the peoples of the Continent, and it is now, with some modifications, again a question for "the parliaments of European states with independent foreign policies." The parliamentary "Gallup poll" on European federation undertaken by Coudenhove-Kalergi had the amazing result of 612 yesses to 12 noes. This time, Britain is in the forefront. Among the 107 members of the British Parliament who have voted for European federation, 64 belong to the Labor Party and 34 to the Conservatives. ${ }^{5}$

Winston Churchill, speaking on May 14,1947 before an assembly of almost all political parties and churches, made himself the advocate of the new European movement. He declared that the real demarcation between Europe and Asia is no natural frontier, but a spiritual conception. His faith in the future of Europe is based on the community of French-English interests, which he recognized in his dramatic offer of common citizenship made in June 1940; the accomplished fact of the Scandinavian union; and the customs union between the Netherlands and Belgium. Churchill stressed the cultural message of Europe to every part of the world. Religion, law, arts, science, industry, throughout the world bear the stamp of European origin.

This great vision would also fill the dangerous vacuum in Germany or the Germanies, a federation of German states accepted from the beginning as full members of the greater European federation.

\section{AMERICA AND EURope}

While the deadlock between the Eastern and the Western world continues, a

${ }^{5}$ Declaration at the second annual New York Herald Tribune Forum on a Parliament for Europe, March 9, 1947. 
resolution to rally American support for a project of Pan-Europe has been introduced in both Houses of Congress by Senator Fulbright and Representative Boggs. As Senator Fulbright stated, the resolution does not mean that we would undertake to impose an American type of federation on the Old World, but that we would pledge support to the forces already working to put an end to the nationalistic anarchy in Europe. Now, if we allow ourselves such long-term objectives as peace through federation, we not only face a difficult job of re-creating a continent, but we have to ask ourselves whether we are prepared for this moral and material support and whether we are sure that our destiny is tied up with Europe's destiny.

This objective is not only a question of power diplomacy; it is based on a deep cultural and moral unity between the United States and western Europe. Europe is the birthplace of our civilization, and the dominant note of our Constitution was first struck in French and British political thought. Even when the United States raised bars against further European immigration, it remained linked to the European nationalities. We have a community of faith and ethics, the heritage of the New World from the Old. America has achieved a federation of states and an assimilation of nationalities which serves as a model for European idealists.

Americans are proud of all the benefits of their Constitution, and conclude that the remedy for all the troubles in the mother countries is federation. Speaking before the National Publishers Association last January, John Foster Dulles, Republican adviser on foreign policy, quoted Hamilton's famous dictum: "To look for a continuation of harmony between a number of independent, unconnected sovereignties in the same neighborhood would be to dis- regard the uniform course of human events and to set at defiance the accumulated experience of ages." $\mathrm{Mr}$. Dulles concentrated not on the whole of Europe-a vast and undefined entity-but on western Europe. Further, he applied the idea to what is the crucial problem of Europe-Germany. Any hope for European unity will dissolve and come to nothing if we simply build Germany back into its prewar pattern. In that event, instead of playing its part in a new Europe, Germany may try again to digest Europe.

Mr. Dulles illustrated his point by stressing the Rhine. If this economic heart of the Continent can be made to work not only for Germany but for neighboring states, then

western Europe at least . . . could develop into a more prosperous and stable land. That, however, is not likely to happen if the German peace treaty merely re-establishes Germany as a single economic unity, subject to only German political control. ... If such dispositions are made Germany's western neighbors-France, Belgium, and Holland-will hesitate to organize their economies into dependence on a source which may again be controlled by vengeful German rulers ... rather than risk that the nations of western Europe will probably annex bits of Germany as they can and, as to the rest, accept economic separation. ${ }^{6}$

\section{Problem of Education}

We are faced with a problem which has a long perspective, the problem of education for unity and community of European nations. This is not a question of charity or of social engineering, but an effort of intellectual co-operation.

The powers meeting at the San Francisco Conference in June 1945 accepted a proposal by the Chinese Government that educational and cultural relations be included within the scope of United

${ }^{6}$ Fortune, Vol. 35, No. 3, March 1947. 
Nations activity, thus avoiding the pitfall of "national sovereignty" which had wrecked the attempt of the League of Nations to include them. The little republic of Haiti, whose representative twenty-three years before had stood alone in the League Assembly to plead for an agency for education, again proposed an agency "to see to it that education should never be used to propagate ideas contrary to peace." It was finally agreed to make specific mention of "international cultural and educational co-operation" in Article 55 of the United Nations Charter.

The Allied ministers subsequently set the date for their next conference in London for November 1945; and on August 1 they released the text of a draft constitution for an Educational, Scientific and Cultural Organization of the United Nations (UNESCO).

The law affiliating the United States with this organization authorized the establishment of a National Commission to serve as an official "bridge" between the Government and private, voluntary groups within the United States. The United States National Commission, consisting of 90 (later increased to 100) leaders in American educational, scientific, and cultural life, held its first meeting in Washington, September 2326, 1946. In its report the Commission agreed that immediate urgency put dissemination of culture in the first place, and proposed a world-wide radio network, expanded agencies, and motion pictures.

The real measure of UNESCO's success will be found in what happens in the minds of men located in all parts of the world and over a period of many years to come. It will not be measured by the amount of organization of a bureaucratic agency, except in the immediately urgent reconstruction and rehabilitation field.

\section{Difficulties and Programs}

UNESCO will have great difficulty to find a neutral formula in the conflict of ideas. Obviously, the program to be devised cannot differ greatly from the present major national cultural relations programs. Nor can one expect, as a challenge to cultural competition, a ready-made answer to all world-wide conflicts. It is the impression of participants and observers that in all gatherings of UNESCO, as in the meetings of the United Nations, there is as much struggle for position as endeavor to find a formula of co-operation.

We have only to look at a few simple facts about contemporary foreign policy to see that this activity of cultural competition is very realistic. What we now term "programs of cultural relations" may be demonstrations of the art of making friends and influencing people, but they are also reliable aids in the business of securing allies. Formidable sums are being expended on these programs, and these sums will doubtless grow larger as the policies to be followed by the several nations are translated into practical effort. Libraries, book stores, publications, institutes, schools, radio programs, films-all these and more are being lavishly supported by alert and astute foreign offices.

The principal question we ask about UNESCO is this: How and to what extent can it temper the process of the conflict of ideas? We may answer first of all that of course it cannot do so by setting up any one philosophy as binding and orthodox. UNESCO is first and foremost the provision of opportunity for participation in world-wide discussion. The right of freedom to speak and be heard may be taken away by dictators, but in the final analysis it can be destroyed altogether only by failure to make use of it. While the practical purpose of the discussion 
which UNESCO creates is to serve the peace of the world by mitigating blind nationalistic hatreds based on mutual misunderstanding or mutual arrogance, the sources of such hatreds are so complex that practically no subject should be eliminated from the discussion.

Here we come face to face with the most difficult single problem which UNESCO faces-the problem of relationships with Russia. UNESCO has not been able to elicit from the Kremlin any expression of opinion about UNESCO, not even an official newspaper editorial, nor have Americans succeeded in bringing about any alteration of Russian policy in the domain of international relations. It is evident that UNESCO will to a great extent fail unless the attitude of Russia toward other peoples can be changed.

\section{"Marx and Freud at UNESCO"}

The adviser of the American delegation to the first general conference in Paris, James Marshall, now member of the New York Board of Education, wrote an excellent article entitled: "Marx and Freud at UNESCO," which appeared in the summer edition of the American Scholar. ${ }^{7}$ I wish to draw from this article, which boldly points out the antithetical premises which must be reconciled if UNESCO is to succeed. James Marshall understands that the issue at hand is a conflict of ideas transcending the organizational framework, and he comes to the conclusion that mere adherence of the so-called Soviet nations to UNESCO will not eliminate the cleavage.

The acceptance of Marx or Freud, economic determinism or psychological healing, opens wide the gap between methods of conflict. and those of cooperation, between ruthless surgery and medical art. Even if any other kind of

`American Scholar, 1947, pp. 304-11. psychology is substituted for the fashionable psychoanalysis, the problem remains the same in terms of objective versus subjective conditions of changing the world or transforming men.

The danger is that we misconstrue the consequences of this divergence of premises. American methods and predilections push us to the naïve assumption that such differences can be removed by appealing to the facts. Facts are "romances of the mind," as the great historian Henry Osborn Taylor wrote in a book of this title. A true understanding of the issue would make it clear that there are several interpretations of the facts, according to one's perspective. We assume, according to our customs and traditions in politics and business, that discussions lead to agreement; however, there must be a common basis of understanding. Let us exchange ideas, we say, let us make treaties permitting the free flow of news and motion pictures, and the frontiers of the mind will automatically be opened. Partial concessions are to provide a modus vivendi.

One need not accept the correctness of dialectical materialism to concede that the pangs of want affect the stability of peace. They arouse anxieties which deprive the sufferers both of the power of reason and of the capacity to understand and have sympathy for others. Even if we share the belief in materialism and concede that cultural education can set in after certain primitive economic conditions are given, we cannot accept and be content with economic determinism. James Marshall said:

We would indeed be blind if we did not recognize that the very transplanting of families and the instability of family life have a decided relationship to material things and institutions, to bread and coal and cloth and bricks, to trade and communication. 


\section{A Question of Tolerance}

It is not economic co-operation, business relations with state trusts, not even good will and good intentions that can adjust the differences and create a fellowship among those with different backgrounds. We are facing a problem of quasi-religious intolerance. Tolerance is not an affair of self-restraint; it is the admission of one's doubts. Tolerance requires a skeptical sense of humor more than a serious goodness of intent. Marshall says: "If we wish to achieve a 'frontierless world of the mind'-as Anne O'Hare McCormick formulated it-we must first look to lower barriers where commerce can find entrance."

This is the formula of compromise in terms of a business world. There is an element of misunderstanding which, unfortunately not realized, creeps into the scheme. An American overlooks the experience of Europeans that the political groups are no longer conservatives and liberals, tories and whigs of the same society with different shades of opinion, but are believers in different philosophies of life and society. In a revolution against the whole existing traditional law and order the fanatics and dogmatists have a universal gospel, and the jealousy of their high priests does not permit any doubt that they guard the depository of the right faith. Just as in medicine, so in politics nowadays quacks offer cures of all evils by panaceas.

\section{The Materialistic View}

This whole problem came into the open in the only speech of a Sovietoriented delegate from Yugoslavia at the opening conference in his attack on the very idea of UNESCO. Vladislav Ribnikar presented the reaction of his government, and presumably that of the Soviet Union, to UNESCO. Mr.
Ribnikar first quoted those phrases of the UNESCO constitution which state "that since wars begin in the minds of men, it is in the minds of men that the defenses of peace must be constructed" and "that ignorance of each other's ways and lives has been a common cause, throughout the history of mankind, of that suspicion and mistrust between the peoples of the world through which their differences have all too of ten broken into war." As to these provisions, Mr. Ribnikar stated:

I feel certain that any man acquainted with the study of history and who has understood the origins of the war which has just ended, will agree that such arbitrary conclusions show a lack of scientific knowledge, that they give an inaccurate picture of the causes which, in the history of mankind, have provoked wars between nations, and that it is impossible with such principles to remove effectively the causes of war.

"It was because of such principles," he said, "that the Yugoslav Government had been prevented from proposing the ratification of the UNESCO constitution to their Parliament."

In the view of Mr. Ribnikar, the philosophy of UNESCO entirely rejects materialistic philosophy.

If materialistic thought were to be banned, it would amount to holding up the creative advance of younger peoples. This would deprive science of the methods by which it has become science, and in the last instance, would amount to subjecting science to metaphysics.

James Marshall says, "The 'science' which proclaims that progress can only be achieved by the destruction of one social order in conflict with another, is a formula for antagonism and a rationalization to justify, if not to induce, aggression." If one believes the only way to achieve the dialectical synthesis, 
the attainment of a united world, is to go through the bloody struggle of class conquest, then obviously the achievement of social equality and collaboration by repressing aggressive drives or harnessing them to constructive purposes must appear to be "arbitrary conclusions" and to present an "inaccurate picture."

\section{Emotional Conflict Remains}

But the solution of economic inequality and the problems of maldistribution will not dispose of those forms of aggression arising out of the emotional patterns created in the family circle. Freud pointed this out:

By abolishing private property one deprives the human love of aggression of one of its instruments, a strong one undoubtedly, but assuredly not the strongest. It in no way alters the individual differences in power and influence which are turned by aggressiveness to its own use, nor does it change the nature of the instinct in any way.

\section{In Marshall's words,}

the seeds of delinquency and bigotry and aggression would still be sown. It is only when educational forces, both formal and informal, are adapted to meeting such problems that the task of constructing the defenses of peace can be completed.

This is the problem of conciliation: How much of conflict, how much of distrust and aggression, can be solved or resolved by attention to the minds of men and to their emotional relations to one another?

\section{Early Attitude Toward Soviet RUSSIA}

Understanding of Russia is not a matter of information or of acceptance of socialist indoctrination and regimentation. It presupposes the acknowledgment of the industrial achievements and the military victory of a far distant country with which we were allied in the crusade against fascism. We cannot understand the situation without the historical background.

From the time it became necessary for the United States to participate in the war against Germany, Italy, and Japan, we were fighting for democracy, but much more was at stake: civilization, the common possession and tradition of the Western nations. Therefore the alliance with a totalitarian state in the war against totalitarian states looked strange to those who had not forgotten the attitude of the United States toward the Soviet regime since 1917. American troops participated in the Allied effort to overthrow the Soviets. The belief that this regime was doomed to failure and that it was threatening our system prevented the recognition of the Russian Government. However, this did not prevent a considerable trade between the two countries. It was certainly not a problem of how to do business with the big, state-controlled corporations of Russia.

By the time Franklin Delano Roosevelt was elected, the Union of Soviet Socialist Republics had reached a position of great influence, and, expanding his good-neighbor policy to Eurasia, President Roosevelt expressed his regrets "that these great peoples between whom a happy tradition of friendship existed for more than a century to their mutual advantage" had no direct communication. "Impelling was the desire of both countries for peace" and hence the establishment of diplomatic relations.

Beginning with the friction ranging from inability to adjust the claims of old war debts with the Soviet counterclaims of compensation for intervention against Communist activities, a real hostility developed when the Soviets signed the treaty of nonaggression with 
Germany in 1939. Stalin had become the accomplice in the conspiracy against the West.

\section{From Friction to FriendShiP}

But almost over night a complete reversal was brought about by Hitler's attack on the U.S.S.R. and our interest in an unexpected ally. The very actions of the Soviets that had antagonized American opinion appeared in retrospect as a farsighted measure of defense. The pact with Germany gave the Soviets time to build up their armament; the pushing back of the Finnish frontier and the annexation of the Baltic states gave them outposts; the FiveYear Plans looked now like a shrewd preparation of a war economy; and finally, the successes of the Russian armies produced a great upsurge of respect and admiration.

There was even a tendency to say that between the two countries there was not so much difference after all. In the interest of better relations one may dwell upon the similarities of industrial nations and of great powers which are a melting pot of many nationalities, and even more upon America as a model for Russia of technical achievements and an economy of plenty. There is even a slight resemblance in the aims of both countries. Neither is based on the old privileged-class system; both are opposed to the Nazi system of nations enslaved by a master race. ${ }^{8}$

However, to Americans even the new Soviet constitution of 1936 has no meaning. We do not like the system of secret police prying into private affairs, the concentration camps of millions of forced laborers, the restrictions on foreign travel, the decrees which freeze workers to their jobs, and so forth. We try to understand the feel-

8 Albert R. Williams, "The Soviets and America," Free World, Jan. 1943, pp. 70-72. ing of insecurity of the Soviet Union living under a threat of invasion, and the backwardness of a country lacking traditions of political freedom for millions of nomads and peasants unable to read and write.

It was supposed that Russia would develop in the direction of greater freedom and American concepts. On the other side, in such fields as planning, social security, and nondiscrimination it was hoped that America would incline to Soviet ideas. Beginning with the assistance in the great famine of the Ukraine and ending with the lend-lease program providing the Soviets facing defeat with the necessary mechanical armament at the time of Stalingrad, we believed there would be a basis for good will and gratitude, mutual recognition and co-operation.

After victory, companions-in-arms often discover reasons for conflict among themselves, and more intimate contact merely emphasizes the distances that separate them in spirit. The war continues in diplomacy, with different means of measuring power.

The friends of Russia speculate that she will fix her attention on the development of her enormous internal resources, and might intervene throughout Europe only if Europe is organized against her or is not organized at all. If neither chaos nor an anti-Communist crusade threatens her security, some politicians think Russia is likely to agree to a European settlement that she thinks will make for peace.

\section{SOVIET INTOLERANCE}

In any event, the single item of Communism on which we concentrate our attention does not explain the more important fact that the Soviets represent the strongest power in Europe-that the U.S.S.R. is not a state but a federation of nations in a new empire and a total 
system of civilization which is not only alien but antagonistic to Western civilization and society. Since Communism is a revolutionary and intolerant confession of faith of universal dimensions, can it stop short of its goal of liquidating the old order in the world?

We are here concerned with the challenge of a system in which everybody is a proletarian against a system in which everybody is or wants to be a bourgeois. The whole idea of rapprochement, conciliation, and toleration is a middle-class idea in Russian eyes. We must understand the intolerance of a new orthodoxy. Assured that they have the right faith, the adherents consider themselves encircled and threatened by evil powers and are suspicious of a "plot." The capitalist is the devil and the masses of capitalist countries are misled. There is no possibility of conversion for the damned. The selected-not at all the working classes in general-have to pass through an educational dictatorship with thought control and purges of the intelligence. The depersonalized citizen of a collectivist machinery is not content with socialism in one country. There is for a Marxist only one incredible fact-that workers in the Western democracies are not only gradually raising their standards, but are organized in powerful unions which the Marxists' own revolution has pushed aside. These reformists who are opposed to catastrophic change were considered Babbitts in I. Ehrenburg's report on America. ${ }^{9}$

\section{EMPHASIS ON POWER}

The role of the Soviets can be understood only in their emphasis on power. In international conferences they have insisted on the distinction between great and small nations. The Soviet leaders

${ }^{9}$ I. Ehrenburg's report on America, Harper's Magazine, Dec. 1946. always stress the fact that they were victorious and that their regime has met the test. They have been building up a centralized regime in which all the heterogeneous peoples forming the Soviet Union were inflamed to defend the fatherland by the same nationalistic slogans as in other countries.

To build up the power of the regime the people had to give up all hope of a better life; and if the production of consumer goods is kept at a minimum, the question as to who owns the plants is not so important, it seems to us. An allpowerful bureaucracy with the largest of standing armies has defended exactly the same position of unrestricted sovereignty as did the most stubborn isolationists. It is no longer a dispute between economic systems; the struggle is tween different economic systems; the struggle is between powers. Historical experience can be cited to show that greater unity in a country or on a continent or even world-wide community can be achieved only by political means.

\section{IDEOLOGICAL CONFLICT}

We are in an ideological war. The importance of propaganda, mass production of opinion, is symptomatic of the new mass civilization. As early as March 1919, Lenin created the first governmental propaganda organization to spread Marxist ideas as a new universal gospel and appeal to all oppressed national groups and exploited classes. Marxist philosophy is dialectical, a belief in the conflict of ideas and forces worked out in a historical process. Ideas serve only as a weapon to discredit the values and reasons of the opponent. When the conflict in peaceful competition and discussion is replaced, in time, by war and revolution, co-operation or community has lost its meaning.

Suppose the Russians know all the 
facts about the West, and that their leaders are well informed about American corporations and unions, parties and Senate debates; why is this knowledge no basis for an understanding? It is because we have different ideas about public opinion and education. We are living in the old age of discussion, thinking that the people must be well informed and that through public debates the truth will become evident as in a law court. In Russia, discussion is allowed only on local affairs and technical improvements. Education is indoctrination and initiation into the technical world. Nothing is so dangerous as technology without humanism.

\section{Machinery Is Not Enough}

International understanding is not an easy formula, because so many issues are involved in the problem-differences of religion, national loyalties, levels of education. It is futile to look for success to the creation of an international agency until in each country the will for international co-operation has been cultivated. "You cannot make good neighbors by the organization of courses and entrust the inculcation of moral standards to an organization. There is no magic in administrative machinery." 10

We must not assume that the technique for bringing about a new meeting of the minds is already available. Mere organization does not inspire teachers with ideas that transcend national culture. The Institute of Intellectual Co-operation shows that the technique of co-ordination was not able to overcome international estrangement. It seems realistic to concentrate on the minimum requirements of international

10 I. L. Kandel, "Re-education on a World Scale," in World Order: Its Intellectual and Cultural Foundations (ed. by F. E. Johnson, 1945), p. 171. order. Constant frustration is likely to lead to the cynical idea that nothing but brutality and stupidity can be expected in power politics.

\section{BeLIEF IN World CoMmunity}

However, that world community is the political ideal of our age can be demonstrated even by the theory of the Marxists, who believe that the world will become one through international technology in a new social order. The differences are on the cultural plane. If community is a consensus of values, as MacIver pointed out, the pursuit of common ends does not presuppose an agreement on all matters, but it does require allegiance to a common cause. We realize how great the regress of universally accepted cultural principles and how different the cultural levels of many peoples are, but we have a passionate belief in greater unity and community in mankind as the meaning of history. Politics is a question of timing. All revolutions are coming of age and at an end of expansion. At this moment of history we can achieve only a unity of the Western world. We are not yet in "One World," but we believe in it.

In the United States as a world power lies the hope of fulfilling the mission and idea of the new world, of transcending the limits of national policy and culture, and of defending the rights of men in a free society. Let me conclude with the exhortation of Alexander Hamilton in The Federalist:

It has been frequently remarked that it has been reserved to the people of this country, by their conduct and example, to decide the important question, whether societies of men are really capable or not of establishing good government from reflection and choice, or whether they are forever destined to depend for their political constitutions on accident and force. If there be any truth in the remark, the crisis 
at which we are arrived may with pro- tion of the part we shall act may, in this priety be regarded as the era in which that view, deserve to be considered as the gendecision is to be made; and a wrong elec- eral misfortune of mankind.

Gottfried Salomon Delatour, Ph.D., is visiting professor at Columbia University, New York City, and at the University of Michigan, Ann Arbor. He has been professor of social philosophy at the universities of Frankfort and Paris; president of the postgraduate international courses in Davos, Switzerland; and consultant to the French Information Service and the United States Office of Strategic Services. He is author of Staatslehre (1930), and editor of the Year-book of Sociology and Social Science series (1926-30). 